PRIFYSGOL

glyndŵn

Glyndŵr University

Glyndŵr University Research Online

Theology

Theology

$1-1-2006$

\title{
Apostolic Networks and Mission
}

William K. Kay

Glyndwr University, w.kay@glyndwr.ac.uk

Follow this and additional works at: http:/ / epubs.glyndwr.ac.uk/theo

Part of the Comparative Methodologies and Theories Commons, and the Religious Thought, Theology and Philosophy of Religion Commons

This is an electronic version of an article that was first published in the Journal of the European

Pentecostal Theological Association in 2006. The journal website is available at

http://www.eptaonline.com/

\section{Recommended Citation}

Kay, W. K. (2006) 'Apostolic Networks and Mission' Journal of the European Pentecostal Theological Association, 26 (2), 156-167

This Article is brought to you for free and open access by the Theology at Glyndŵr University Research Online. It has been accepted for inclusion in Theology by an authorized administrator of Glyndŵr University Research Online. For more information, please contact d.jepson@glyndwr.ac.uk. 


\section{Apostolic Networks and Mission}

Revd Dr William K Kay

Professor in Theology

Academic Leader for Humanities and Theology,

Glyndwr University, Wrexham

(When article published on this website)

Revised and abbreviated

Correspondence

Revd Dr William K Kay

Email:w.kay@glyndwr.ac.uk 


\section{Introduction}

Around 1990 Paul Cain gave a prophecy to a New Frontiers leaders' meeting in Brighton. He said,

This is a matter of a sovereign work of apostolic character and nature and chemistry and the Lord is going to use it to change the expression of Christianity all over the world. And that's the word I came to bring. The Lord will use you here in a sovereign way to change the expression of Christianity throughout the world (Virgo, 2002: 192)

The prophetic announcement given by Cain indicated that New Frontiers International was to make ground-breaking changes to the expression of Christianity and, consequently and among other things, to the way mission is carried out. To understand this fully and to assess whether the announcement is credible, it is necessary to look back on Protestant missionary enterprises to see historically how they have operated. The focus here is largely upon the structures through which mission is actuated rather than the theology driving it though, as we shall see, theology is of crucial importance in the conduct of mission within apostolic networks.

\section{Typology of missionary societies}

Klaus Fiedler (1994) devised a typology of Protestant missionary movements and arranged them on a timeline. Like many others (e.g. Latourette, 1976; Edwards, 1997) he regards An Enquiry into the Obligation of Christians to Use Means for the Conversion of the Heathen written by William Carey in 1792 to be crucial. The first group within his typology comprises denominational missionary societies (like the Baptist Missionary Society of 1793) that were organised independently of any individual congregation but were strongly related to the denomination as a whole. Missionary societies were usually organised as voluntary associations 'in which every member other than the missionaries -- to whom the principle of voluntary association did not apply because they were employed by the mission -- had a say' (page 20). These denominational missionary societies reflected the internal structures and ecclesiologies of the denominations with which they were connected.

The second group are inter-denominational missionary societies. The first of these was the London Missionary Society of 1795 and it followed a similar pattern apart from the greater range of congregations offering financial support. Within such missionary societies a board was convened for the control of missionary activity in ways similar to those utilised by denominational missions. Regular communication to and from the field enabled the board to feel that it had an appreciation of the progress and problems confronting individual missionaries; boards responded by giving written instructions and sending or withholding money. The Basle Mission founded in 1815 functioned in this way and regularly sent out men and women to Africa where, in the early years, most of them died. In one gruesome statistic, there were for several years more deaths among missionaries than converts. As the mission boards became more adept at their work, language training, cultural preparation, biblical teaching, financial systems and the provision of visas and other documents, became part of their role. Missionaries, in both denominational and inter-denominational missions, often confined themselves to mission stations or secure compounds where they lived in relative safety and with the ability to go out to preach, offer medical help, supervise the 
building of schools and run local congregations. ${ }^{1}$ Inter-denominational missionary societies were obliged to ensure that no doctrinal controversy among the missionaries themselves blighted the work and it was common, in such circumstances, for policies on water baptism to be settled in advance (Fiedler 1994: 21).

As ecumenical and liberal movements took place within the churches of Europe and North America, denominational and inter-denominational missionary societies converged and differences between them became blurred (Fiedler, 1994: 21). In both instances the missionary was the agent of the board. It seems incredible to 21 st century commentators that, for example, the Basle Mission should send out wave after wave of young men and women to work in appalling conditions where their life expectancy was low, where they had little control over what they did and where there could be disciplined by the withholding of finance if they disagreed with the board's decisions. In many instances those who were sent out, however, were tenant farmers or in other ways obligated to their social superiors who sat on the board. 'People like us have always told people like you what to do' was the attitude of the board and an attitude accepted by the missionaries. ${ }^{2}$ Denominational missionaries appeared to fare little better even though, in theory, those who sat on the board, were fellow members of the same denomination. Had the missionaries functioned as ministers within their own country, they would never have accepted the interfering directives that they had to put up with on the field.

In 1865 Hudson Taylor founded the China Inland Mission (CIM) and established it along faith lines; that is to say, CIM missionaries received no salary beyond that which they received through prayer to God communally and centralised distribution on the field. The missionaries were not employees of the mission or subject to the board but were members of the mission and, more than this, their calling to China took pre-eminence over cultural norms within the country of their origin. CIM Missionaries were expected to identify with the Chinese people, to dress like them, to eat their food, to learn their language and, when strategic decisions had been made, these were made on the field by other missionaries within the same society and not handed down from distant boards in the countries where money was collected. ${ }^{3}$ Faith missions were the third group in the typology.

It should be emphasised that this discussion is not intended to diminish the heroic and sacrificial efforts of many missionaries in the $19^{\text {th }}$ century. ${ }^{4}$ Nor is it intended to be an exhaustive classification system. Mission societies changed over the course of time and could diversify their activities so that they became less close to their originating type. For instance, although faith-based missions were intensely evangelical, they could also engage in charitable works like the building of schools and hospitals (as was the case with the CEM founded by W F P Burton in $1919^{5}$ ). Equally faith missions might also be interdenominational in their composition -- as was the CIM -- while inter-denominational missionary societies might emphasise to their missionaries that funds could not be guaranteed and that, as a consequence, personal faith for provision was required. The Pentecostal

\footnotetext{
${ }^{1}$ According to Fiedler the strategy might be to set up a chain of mission stations across hostile terrain each fifty hours of travelling time from the next, $\mathrm{p} 73 \mathrm{f}$.

2 Jon Miller's answer at EPTA 2005 to a question posed during a visit to the Basel Mission.

${ }^{3}$ It is true that later pledged support was used by these missions, cf SIL/Wycliffe.

${ }^{4}$ Protestant missions in Africa trebled between 1886 and 1895. Many died young (Ferguson, 204: 158, 160).

5 Though the earliest form of association dates to 1915. Burton himself was an apostle by any definition of the word and the Congo Evangelistic Mission he founded showed many of the characteristics of an apostolic network.
} 
Missionary Union made this kind of stipulation: its missionaries were not guaranteed an income even though the PMU council in Britain did attempt to raise money interdenominationally and to control the activity of its missionaries from afar. ${ }^{6}$ During the $19^{\text {th }}$ century and within the first part of the $20^{\text {th }}$ century many missionary societies were founded so that, for instance, Fiedler needs nine pages to enumerate all the different societies, particularly since the sending countries were situated all over the world ( $\mathrm{pp}$ 92-101). Between 1918 and 194019 new missionary societies were founded solely for the evangelisation of central Africa.

\section{Denominations and networks}

Alongside this typology of missions, can be placed a typology to include denominations and apostolic networks. The denomination is usually contrasted sociologically with the church where 'church' is applied to a broad grouping like Roman Catholicism that stretches its jurisdiction well beyond national boundaries (Weber, 1930; Wilson, 1963; Berger, 1967; Bainbridge, 1997; MacLaren, 2004). Churches may also be more limited and operate within nation states and, in such circumstances, are often identified with the ruling elite. Anglican churches are part of the British establishment and their bishops have, by right, seats in the House of Lords. Traditional religious structures, as we shall see, contrast with such structures as are put in place by apostolic networks.

Within the Presbyterian systems ministers are all equal with each other but power is vested in bodies to which ministers may be elected and to which all have an equal chance of being elected. Each congregation may have its own presbytery and then, above this, may be a regional presbytery or an executive presbytery. It is not that the individuals who sit on the executive presbytery outrank ministers on presbyteries lower down the system but that one presbytery, defined by constitution, does outrank another. The voting system expresses the reality of the equality of the ministers within their denomination. The constitution, because it is also agreed by voting, ensures that where denominational authority is exercised, consent is implied.

Denominational missionary societies set up within this structure operate by electing members to a presbytery or collective group (which may be called a Missions Council or Missions Board) and this has power over the special category of ministers within the denomination that are designated missionaries. In this sense the missionaries are directly subject to a higher authority within their denomination. Additionally missionaries are not able to be both on the home board or council and, at the same time, to be on the field; distance precludes this. Consequently missionaries are always excluded from and subservient to their governing body and, since they must communicate with it individually and directly, are rarely able to act collectively to make their opinions count.

The point is that missionaries are answerable to their boards within denominational settings. In the case of inter-denominational missionary societies, the board also wields power since it collects the finance from contributing churches. In practice, it is difficult to discern a greater degree of missionary autonomy within inter-denominational missions than is the case in denominational missions. In short, it is arguable that many missionary societies of the $19^{\text {th }}$ and early $20^{\text {th }}$ centuries derived their ethos from the social and theological presumptions of the denominations of their day. These denominations were largely authoritarian in outlook,

\footnotetext{
${ }^{6}$ It is also true that Cecil Polhill's Practical Points Concerning Missionary Work did distinguish between mission stations and church planting. It also warned against becoming occupied with education, medicine and philanthropy.
} 
and their hierarchies ran in precise parallel with the social stratification of the age. ${ }^{7}$ Only faith missions where authority is vested in a collection of missionaries on the field can be seen to give missionaries the degree of control over their own lives and strategy that many of them might wish. Only faith missions escaped the worst results of class-based governance.

In almost every case the work of missionaries is determined by someone other than themselves. It is true, and was especially true when global communications were slower and more fragile than they are today, that missionaries in practice enjoyed a measure of autonomy whatever their mission boards might dictate. Nevertheless the missionary was obliged to carry out tasks assigned to him or her by the board, and the tasks did not necessarily, or even usually, involve the planting of churches. Missionaries were teachers, evangelists, carers, supporters and administrators within indigenous churches but the planting of churches was rare partly because this capacity required rare gifting but also because church planting was uncommon within the Christian culture from which the missionary had come. For example, for many years the Baptists in Britain planted no new churches and so it is hardly surprising that their missionaries overseas were also deficient in this respect.

Apostolic networks were established in the 1970s in Britain. They defined themselves by avoiding the obvious hallmarks of denominations and emphasised that their own method of 'doing church' was relational rather than hierarchical or official. Where denominations set up hierarchical systems, apostolic networks ensured that their own structures were as flat as possible. Where denominational systems achieved decision-making through voting, apostolic networks eschewed all forms of balloting. Where denominational systems appointed committees, apostolic networks prioritised spiritual and ministry gifts. Essential to the structure and functioning of apostolic networks was the role of the apostle himself (in almost every case this was a male). The apostle was viewed as someone with a God-given the capacity to plant and design congregations. He was, in Paul's words, a 'master builder' (1 Cor 3.10) and specifically modelled on the apostolic pattern found within the Book of Acts and in the Pauline epistles. The apostle was concerned primarily and specifically with the creation of new congregations and, once a congregation had been planted, it was the apostle who had the authority to appoint elders. ${ }^{8}$ Apostolic networks are consequently made up of a series of autonomous congregations governed by elders over whom there is an apostolic figure who normally works within a complementary team of ministers. The connection between the autonomous congregations and the apostle is relational: it is not legal or encased in denominational tradition. The apostle does not own the building used by the congregation nor does he have the right to impose his will upon the congregation's elders even though, in practice, the elders, since they have been appointed by the apostle, are likely to value his advice.

Although the apostolic network carries echoes of an episcopal system of government (since the apostle is analogous to the bishop) there are huge practical differences between the two forms of operation. Whereas within an episcopal system the bishop outranks all those within his diocese and, by virtue of ecclesiastical law or constitutional precept, has power over the congregations and ministers under his charge, the apostle has a lighter touch. Moreover, and importantly, the apostle is not put in place by a voting system or by government appointment

\footnotetext{
${ }^{7}$ Thousands of young men were sent, apparently uncomplaining, to their deaths in the trenches of the 1914-18 war. This was an age of duty and deference.

${ }^{8}$ See Mayho, S 'Do not be hasty in the laying on of hands' (1 Tim 5:22): The Role, Recognition and Release of Leadership in the New Testament and Their Relationship to Recruitment in the Church Today. MTh Dissertation, University of Wales, 2006, section 5.8.
} 
but is a truly charismatic leader whose authority stems from his gifting and ministry. ${ }^{9}$ The congregations ask the apostle if he will take them under his wing and, since the apostle has a record of planting churches or of re-structuring older ones, it is apparent that the apostle possesses the gifts that define his calling. Or, to put this another way, bishops are appointed to fill empty spaces within an ecclesiastical structure, and the man appointed in this way may or may not be suitable for the task. Apostles draw a network around them and are only able to do so because of their obvious gifts.

When apostolic networks begin to work overseas, it is the apostles who begin to plant churches in new locations and to appoint elders in new fields. This is where the contrast is most sharp. With traditional missionary work, the missionary is sent to function within a new field while the bishop or denominational officials stay at home. In the apostolic network, it is the apostle who goes overseas and facilitates the work and who then calls upon the resources of the network at home to support the church overseas. So missionary work in apostolic networks is typically performed by apostolic figures who, to use conventional terminology, are the most senior people within their grouping. This immediately changes the dynamics of the entire process. Mission is driven from the top of the church and not from the bottom. Additionally the apostle is a travelling figure who may stay a short while overseas ministering to elders and congregations and who, on his return home, has the influence to send out other people within the network for short-term purposes. The apostle is not, like the missionary, sent overseas where he may be forgotten but comes and goes as he sees fit. The apostle, unlike the missionary, can set up training in the home country or determine what social or medical needs could best be deployed overseas.

The great strength of the apostle in networks in respect of church planting is that it is apostles who have planted or facilitated new churches within their own cultures who venture overseas to carry out the same function there. Equally important is the determination of apostolic networks, and of New Frontiers International in particular, to confine their work within the parameters of local churches. There is, as a result, no missionary parachurch organisation separate from the local church with its own financial responsibilities and authority structure. On the contrary parachurch organisations -- and missionary societies must be seen in this light -- are deemed to be outside the New Testament pattern and therefore undesirable.

\section{Examples and reflections}

All the major apostolic networks within Britain have overseas work. New Frontiers International, as the largest network, best exemplifies the strengths of the new form of organisation. The early contact with overseas churches were through the travelling ministry of the founding apostle, Terry Virgo, and can be traced directly to his preaching itineraries in India, in South Africa and in North America and in other parts of the world. The decisionmaking systems within New Frontiers International are, as we have already said, specifically charismatic. About three times a year the leaders within local churches in Britain are called together for two days of prayer and fasting and, at these events, prophetic utterances and visions are manifested. The prophecies are recorded and subsequently evaluated by the apostolic team but they function to provide not only a huge stream of creative impulses but also to motivate the assembled leaders. There is no debate at these gatherings where a vote for a proposition may be passed by the $51 \%$ to $49 \%$. Rather the leaders who gather come to pray and, once charismatic utterances are given, the content of these utterances may be

\footnotetext{
${ }^{9}$ Senior positions, including Archbishops, within the Church of England are appointed by the Prime Minister though, obviously, he takes advice from the church. But for many Anglicans this arrangement expresses the church's undesirable subservience to the state.
} 
woven into intercessory prayer. In this way leaders leave the meetings motivated to carry out prophetic direction even if the transformation of prophetic utterance into policy rests with the apostolic team using whatever methods seem fit to it.

New Frontiers International grew rapidly in the 1980s and early 1990s but, as the overseas work became more important, prophetic insight provided a vision of a bow and arrow, with the bow being pulled back over northern England and fired south. This showed how the balance between the work at home and work overseas needed to be re-adjusted. There was no point in concentrating entirely upon overseas work to the detriment of work at home. Equally the work at home did not exist simply as a self-contained Christian enterprise. It existed within wealthy Britain for the sake of poorer countries. So church planting was initiated in Britain conscious that successful new congregations would help resource mission overseas.

There is, in this way, a seamless connection between what is taking place at home and what is taking place overseas. In both locations there is church planting and the justification for this is that the New Testament pattern knows no other way to establish the gospel in any geographical area. Congregations are the forum for the development of spiritual and ministry gifts and there is no human culture that negates this principle. The dynamics of congregational growth at home can be the same as the dynamics of congregational growth overseas.

Although faith is fundamental to everything that is carried out by New Frontiers International, the faith principle is not elevated to the basis of life as it was in the faith missions. This means that resources are moved around the network to meet the needs of the poorer parts of it without a danger that men and women working overseas will find themselves impoverished or insensitively controlled by a supervisory body. Indeed it is arguable that the benefits of the faith missions (the devolution of decisions to the field, an incarnational theology encouraging missionaries to identify with the local culture and freedom to operate with a range of church configurations) are also to be found within the overseas work of New Frontiers. Certainly there is a devolution of decision-making to the overseas location, especially when fresh apostles emerge within the network, as happened in the case of New Frontiers where one of the apostolic team in Britain went overseas to lead the work in South Africa. Equally, particularly because elders are appointed from indigenous congregations, there is an implied incarnation theology that permits local churches to organise themselves as they wish though, clearly, the style of worship and ministry will tend to follow what has been tried and tested in Britain.

\section{Theology and practice}

The theology that drives apostolic networks flows out of a restorationist matrix. Because of the outpouring of the Holy Spirit at the beginning of the 20th century, charismatic gifts are being restored the church. For the same reasons apostolic and ministry gifts (Eph.4:11) have also been restored. Apostolic gifts are historically therefore an expression of restorationist theology and are not the product of power struggles within denominational hierarchies. Moreover apostolic gifts are seen as intended to produce congregations. In this they contrast with various types of mission, particularly faith missions, where the driving motivation was concerned with the salvation of the lost. The missionary society in the $19^{\text {th }}$ century might be seen as a mechanism designed to rescue men and women from a hell. This is not to denigrate these missions since their motivation needed to be powerful to move them out of the comfort of civilised Europe into the more primitive conditions to which they went. But the point of 
the contrast is to show that whereas missionary societies were concerned with evangelistic activities that might lead to the formation of congregations, apostolic activities are primarily set on building congregations. Both kinds of mission may superficially appear to generate the same result but, in reality, there are enormous differences between them. In practice networks produce congregations that are themselves apostolic: the churches are not only restorationist in orientation in terms of ministries and charismatic gifts but also are inspired to produce indigenous apostles who will further extend the network.

Equally there are differences between the old-style missionary societies and apostolic networks in relation to exit strategies. The exit strategy of the old-style missionary society concerns the gradual withdrawal of the missionary from control over the entire operation to an advisory or supportive role and then complete departure. Apostolic networks have no exit strategy because congregations are connected with the apostle and remain connected whether the apostle is in one country or another. In this respect apostolic networks deal with their congregations in exactly the same way regardless of the country where the congregation is situated. There is no need for the apostolic network to devise a transitional exit strategy. The network appoints elders and the elders run the congregation with the supervisory help of the apostolic team.

It is arguable that the theology of apostolic networks is more closely based on the bible than the theology of missionary societies. Missionary societies base themselves on the Great Commission of Matthew 28 and take the words of Christ given to the original disciples as a binding on all Christians. Normal exegetical methods would presume that the best way to understand the Great Commission would be to see how it functioned within the life of the early church, particularly within the Book of Acts. Here it is evident that the commission was carried out by apostles and the paradigmatic example of this is to be found in Acts 13 where Paul and Barnabas are sent out by the church at Antioch. Paul and Barnabas are the first missionaries. Yet, as Acts 14.14 indicates, Paul and Barnabas are 'apostles' and, as the first missionary journey is examined, it is evident that the work of these two men led to the founding of congregations. In this respect the example of Paul and Barnabas, the work that they did, the relatively short duration of their missionary trip, the charismatic gifts with which they were endowed, the guidance of the Holy Spirit both in initiating the journey and on the way, are very different from what is typical among missionaries in the 19th and early 20th centuries. Seen in this light apostolic networks conform much more closely to the Acts pattern than does the work of missionary societies. Terry Virgo puts it this way:

The word 'missionary' obscures rather than clarifies, since it does not honour Biblical definitions and categories. A modern missionary may be an agricultural worker, a nurse, a schoolteacher, a Bible translator, or a literature distributor (all very worthwhile and wonderful ministries). Some missionaries may in reality be evangelists or apostles. But the term is vague and unhelpful, since it has come to indicate anyone who works overseas. Historically, some have established 'mission stations' rather than churches. ${ }^{10}$

[without apostles] local churches were seen as static and built on Scripture, while isolated individuals could leave those churches and become 'missionaries'. In

${ }^{10}$ http://www.newfrontiers.xtn.org/magazine/vol2issue4/article_index.php?id=147 (accessed 28.06.06) 
contrast, our burning passion is to see apostolic churches focused on world mission together. ${ }^{11}$

It may be that the days of the missionary society are, in any case and for other reasons, already numbered. ${ }^{12}$ This is because charity law in western countries places the control of assets within the hands of trustees who cannot themselves be beneficiaries of the trust they are administering. Thus missionary societies that currently delegate decision-making to the field may find themselves having to withdraw these governmental rights. This will complicate future missionary work and, in addition, as a consequence of anti-terrorist and money laundering regulations, missionary societies may find themselves much more closely scrutinised in respect of the transfer of funds. It would appear that apostolic networks are better placed to avoid the destruction of their overseas work than missionary societies.

\section{Conclusion}

Is too early to say whether apostolic networks will change the face of Christianity as Paul Cain predicted but there is evidence that they may change the face of missions. As yet, the impact of apostolic networks, particularly British ones, on traditional mission fields is relatively small though, given the numbers of people involved and the amount of time that has elapsed since apostolic networks were founded, impressive. Although this paper has considered New Frontiers International, there are other apostolic networks springing up from the non-western world. These also may have an impact upon emerging nations and even upon traditionally Muslim nations. It is too early to make a judgment. What does seem evident from this analysis is threefold: apostolic networks have the capacity to function as missionary organisations; they fit the post-modern, globalised, non-hierarchical world well; and, in doing so, they have both theological and practical advantages over old-style missionary societies, even the faith-based societies that delegated decision-making to the field.

\section{Bibliography}

Bainbridge, W.S. (1997), The Sociology of Religious Movements, London, Routledge.

Berger, P.L. (1967), The Sacred Canopy, New York, Random House.

Ferguson, N. (2004), Empire: how Britain made the modern world, Harmondsworth, Penguin.

Fiedler, K. (1994), The Story of Faith Missions, Oxford, Regnum.

Latourette, K.S. (1976), A History of the Expansion of Christianity, Grand Rapids,

Zondervan. Edwards, D L (1997), Christianity: the first two thousand years, London, Cassell.

MacLaren, D. (2004), Missional Implausible: restoring credibility to the church, Carlisle, Paternoster.

Virgo, T. (2001), No Well-Worn Paths, Eastbourne, Kingsway.

Weber, M. (1930), The Protestant Ethic and the Spirit of Capitalism, London, Unwin University Books.

Wilson, B.R. (1963), A typology of sects in a dramatic and comparative perspective, Archives de Sociologie de Religion vol 16, pp 4, 9-63.

\footnotetext{
${ }^{11} \mathrm{http}: / /$ www.newfrontiers.xtn.org/magazine/vol2issue4/article_index.php?id=147 (accessed 28.06.06)

${ }^{12} \mathrm{I}$ am indebted to Dr David Garrard for this information.
} 